\title{
Anti-inflammatory and Anti-arthritic Activities of Aqueous Extract and Flavonoids from Tripodanthus acutifolius Leaves in Mice Paw Oedema
}

\section{()(1) $\odot$}

\author{
Authors \\ Luis Apaza Ticona1, 2®, Andreea Madalina Serban³, Daly Apaza Ticona4, Karla Slowing²
}

\section{Affiliations}

1 Department of Organic Chemistry, Faculty of Sciences, University Autónoma of Madrid, Madrid, Spain

2 Department of Pharmacology, Pharmacognosy and Botany, Faculty of Pharmacy, University Complutense of Madrid, Madrid, Spain

3 Maria Sklodowska Curie University Hospital for Children, Constantin Brancoveanu Boulevard, Bucharest, Romania

4 Clin \& Gen SRL Laboratory, La Paz, Bolivia

\section{Key words}

Loranthaceae, Tripodanthus acutifolius, flavonoids, anti-inflammatory, anti-arthritic, TNF- $\alpha$

received 13.02 .2021

revised 21.03.2021

accepted 30.03.2021

published online 2021

\section{Bibliography}

Planta Med Int Open 2021; 8: e43-e55

DOI 10.1055/a-1471-8947

ISSN 2509-9264

(c) 2021. The Author(s).

This is an open access article published by Thieme under the terms of the Creative Commons Attribution-NonDerivative-NonCommercial-License, permitting copying and reproduction so long as the original work is given appropriate credit. Contents may not be used for commercial purposes, or adapted, remixed, transformed or built upon. (https://creativecommons. org/licenses/by-nc-nd/4.0/)

Georg Thieme Verlag KG, Rüdigerstraße 14,

70469 Stuttgart, Germany

\section{Correspondence}

Prof. Dr. Luis Apaza Ticona

Department of Organic Chemistry, Faculty of Sciences

University Autónoma of Madrid

Madrid

28049

Spain

Tel.: + $34914977622,+34914974715$ luis.apaza@uam.es; Inapaza@ucm.es

$\Theta$ Supplementary Material is available under https://doi.org/10.1055/a-1471-8947

\begin{abstract}
Tripodanthus acutifolius, commonly known as Jamillo, is an herbal remedy used in traditional Andean medicine to treat joint problems, such as sprains, dislocations, and rheumatic pain. This study aimed to evaluate the in vitro and in vivo antiinflammatory and anti-arthritic activity of the aqueous extract and isolated compounds of $T$. acutifolius. A bioguided phytochemical analysis based on NMR/MS was performed to identify the compounds of the aqueous extract from $T$. acutifolius. The anti-inflammatory and anti-arthritic activity were evaluated by measuring inflammatory parameters (TNF- $\alpha$, C-reactive protein, and fibrinogen) in murine models. The chemical structure determination led to the identification of four flavonoids: (E)-2',4'-dihydroxy-6'-methoxy-chalcone (1), 6,2',4'-trimethoxyflavone (2), 5,3',4'-trihydroxy-6,7,8-trimethoxyflavone (3), and 5,4'-dihydroxy-6,7,8-trimethoxyflavone (4). All compounds inhibited the production of TNF- $\alpha$ in the RAW 264.7 cell line, with $\mathrm{IC}_{50}$ values of $0.78,1.43,5.73$, and 9.71 $\mu \mathrm{M}$, respectively. In addition, all flavonoids decreased the levels of TNF- $\alpha, C$-reactive protein, and fibrinogen at a concentration of $5 \mathrm{mg} / \mathrm{kg}$ in murine models. Our research shows that these compounds isolated from $T$. acutifolius have anti-inflammatory and anti-arthritic properties, providing scientific evidence for the traditional use of this plant species.
\end{abstract}




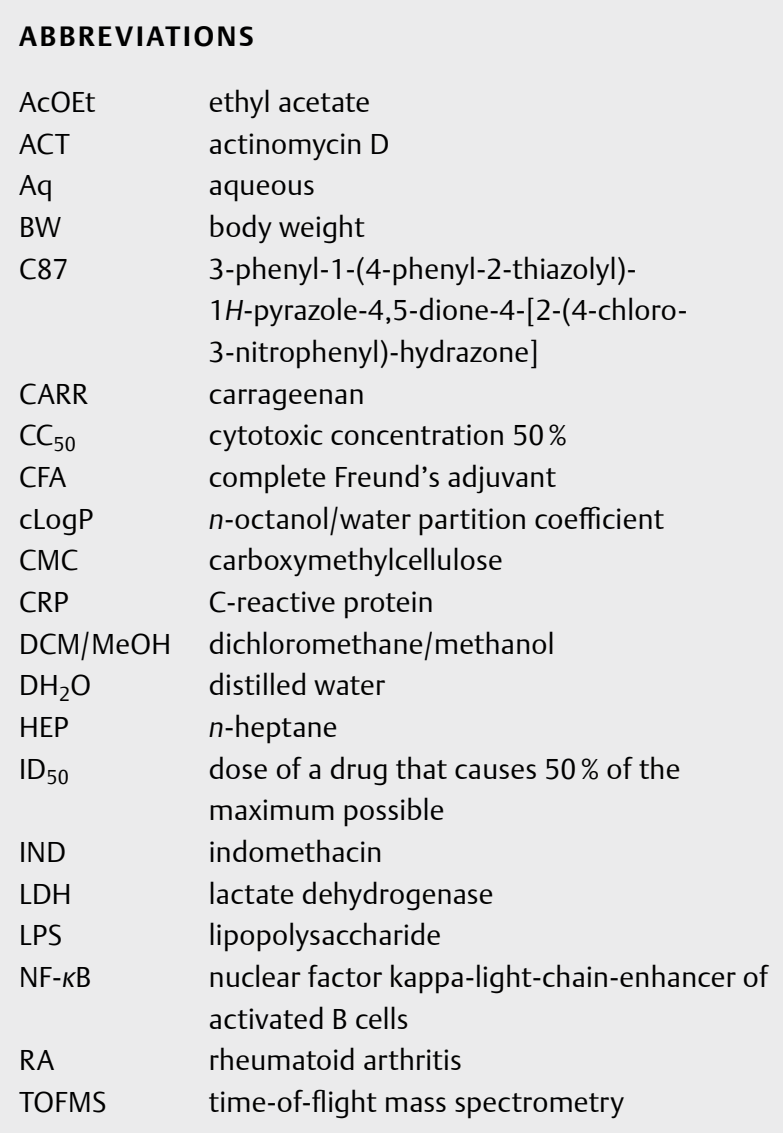

\section{Introduction}

Inflammation is a response of self-protection from the body against the harmful agents that are involved in damaging living cells and tissues [1]. It provides assistance to the body to get rid of harmful agents and helps in initiating the process of healing [2]. Inflammation is usually manifested by redness, swelling, heat, pain, and dysfunction (alteration or functional deficiency of an organ), in which many kinds of cells (mostly macrophages and dendritic cells) and active ingredients (cytokines, chemokines, and bioactive amines) participate [3].

RA is a prevalent form of inflammatory autoimmune disease that affects $1-2 \%$ of the world population [4]. RA is an autoimmune disease characterised by chronic inflammation and proliferation of synovial tissue with invasion of immune cells into the interface between bone and cartilage [5]. The inflammatory synovium elicits the generation of a pannus structure, an abnormal layer of granulation tissue, causing progressive bone erosion and cartilage destruction [6]. In particular, a proinflammatory cytokine-mediated inflamed synovium is crucial for early RA disease progression [7].

The proinflammatory agent TNF- $\alpha$ is a key cytokine of inflammation, which further manifests in tissue destruction [8]. TNF- $\alpha$ is secreted by the monocytes and macrophages in response to inflammatory agents, cachexia, and septic shock [9]. In addition to this, the proliferation of synovial fibroblasts occurs and contributes to the secretion of cytokines and matrix-degrading proteases, thus leading to pannus formation [10]. This causes the loss of joint func- tion and mobility, progressive degradation of the cartilage, and deterioration of the bone [11]. Additionally, the overexpression of TNF- $\alpha$ and proliferation of synovial cells are main features of RA, thus being the potential therapeutic targets for managing this condition [12].

Commonly used medications against RA include nonsteroidal anti-inflammatory drugs, glucocorticoids, and biopharmaceuticals (primarily tumour necrosis factor inhibitors) [13]. Currently, the treatment of RA has been revolutionised by the discovery of the role of certain cytokines, in particular TNF- $\alpha$, in the pathogenesis of the disease $[14,15]$. The approach of targeting TNF- $\alpha$ has considerably improved the treatment of RA [16]. Since the first development of TNF$\alpha$ inhibitors in RA in the 1980s, different drugs (infliximab, adalimumab, etanercept, golimumab, and certolizumab pegol) have shown excellent efficacy $[17,18]$. However, the needs of patients with RA are still unmet because of the severe side effects, inability to achieve a permanent cure, and the high expenditure of these drugs [19]. Thus, it has become important and essential to develop safer and more cost-effective TNF- $\alpha$ inhibitors [20].

Many natural compounds belonging to various classes have been found to reduce TNF- $\alpha$ levels [21,22]. These natural compounds have been found to interfere with various proinflammatory mediators and targets, such as NF- $\kappa$ B and other signalling molecules, involved in TNF- $\alpha$ expression and, thus, could provide alternative means for treating inflammatory diseases by modulating the production of TNF- $\alpha[23,24]$.

In South American countries (Argentina and Bolivia), the infusion of Tripodanthus acutifolius (Ruiz \& Pav.) Tiegh. species is one option for treating inflammation problems [25], especially those of the joints, as well as sprains [26], luxation, rheumatic pains, and bone fractures [27]. It is a species of the Loranthaceae family, popularly known as “jamillo", "jamillu”, or "solda solda o liga” [28, 29].

Phytochemical studies of $T$. acutifolius revealed the presence of several phenolic acids, hydroxycinnamic acids, tannins, flavonoids, and tripodantosides [30-32]. Apaza et al. [33] suggested that (E)2',4'-dihydroxy-6'-methoxy-chalcone, 6,2',4'-trimethoxyflavone, 5,3',4'-trihydroxy-6,7,8-trimethoxyflavone, and 5,4'-dihydroxy6,7,8-trimethoxyflavone were the main compounds responsible for the anti-inflammatory action of $T$. acutifolius. It was also observed that flavonoids isolated from the leaves of $T$. acutifolius, like 3-O-diglucosyl-5,7,3',4'-tetrahydroxy-8-metoxyflavone, among others, possess antioxidant activity [30]. Thus, T. acutifolius shows an abundance of metabolites that are pharmacologically active.

Taking this information into account, the present work was carried out to evaluate the anti-inflammatory and anti-arthritic activities in mice paw oedema of the Aq extract and four flavonoids isolated from T. acutifolius.

\section{Results and Discussion}

The NMR and MS analysis results confirmed the presence of the flavonoids (E)-2',4'-dihydroxy-6'-methoxy-chalcone (1), 6,2',4'-trimethoxyflavone (2), 5,3',4'-trihydroxy-6,7,8-trimethoxyflavone (3), and 5,4'-dihydroxy-6,7,8-trimethoxyflavone (4) in the DCM/ $\mathrm{MeOH}$ fraction of the Aq extract ( $\triangleright$ Fig. 1). All compounds were identified based on NMR and MS spectroscopic data interpretation with the compounds described by Apaza et al. [33]. 
The Aq extract of $T$. acutifolius did not show statistically significant cytotoxic effects $\left(\mathrm{CC}_{50} 98.33 \mu \mathrm{g} / \mathrm{mL}\right.$, p0.074) when compared to the positive control $\left(A C T, C_{50} 10 \mu \mathrm{g} / \mathrm{mL}\right.$ ) in the RAW 264.7 cell line ( $\triangleright$ Fig. 2). Regarding the cytotoxicity of the fractions of the $\mathrm{Aq}$ extract, the results showed that the HEP $\left(C_{50} 91.07 \mu \mathrm{g} / \mathrm{mL}\right), \mathrm{DCM} /$ $\mathrm{MeOH}\left(\mathrm{CC}_{50} 96.92 \mu \mathrm{g} / \mathrm{mL}\right)$, and $\mathrm{Aq}\left(\mathrm{CC}_{50} 98.18 \mu \mathrm{g} / \mathrm{mL}\right)$ fractions did not show relevant cytotoxicity ( $\mathrm{p} 0.074)$ when compared to the positive control (ACT, $C_{50} 10 \mu \mathrm{g} / \mathrm{mL}$ ) in the RAW 264.7 cell line ( $>$ Fig. 2).<smiles>COc1cc(O)cc(O)c1C(=O)/C=C/c1ccccc1</smiles>

(1)<smiles>COc1c(OC)c(O)c2c(=O)cc(-c3ccc(O)c(O)c3)oc2c1OC</smiles>

(3)<smiles>COc1ccc(-c2cc(=O)c3cc(OC)ccc3o2)c(OC)c1</smiles>

(2)<smiles>COc1c(OC)c(O)c2c(=O)cc(-c3ccc(O)cc3)oc2c1OC</smiles>

(4)
- Fig. 1 Chemical structure of (E)-2',4'-dihydroxy-6'-methoxychalcone (1), 6,2', 4'-trimethoxyflavone (2), 5,3',4'-trihydroxy-6,7,8trimethoxyflavone (3), and 5,4'-dihydroxy-6,7,8-trimethoxyflavone (4) from T. acutifolius.
The Aq extract of $T$. acutifolius showed an anti-inflammatory capacity (inhibition of TNF- $\alpha$ ) at an $\mathrm{IC}_{50} 58.39 \mu \mathrm{g} / \mathrm{mL}$ (p0.074) when compared to the positive control $\left(\mathrm{C} 87, \mathrm{IC}_{50} 0.055 \mu \mathrm{g} / \mathrm{mL}\right)$ in the RAW 264.7 cell line ( $\triangleright$ Fig. 3 ). Concerning the anti-inflammatory capacity of the fractions from the Aq extract, the results showed that the $\mathrm{DCM} / \mathrm{MeOH}\left(\mathrm{IC}_{50} 43.95 \mu \mathrm{g} / \mathrm{mL}\right)$ fraction presented a higher inhibitory activity of TNF- $\alpha$ than the fractions $\mathrm{HEP}\left(\mathrm{IC}_{50} 78.70 \mu \mathrm{g} /\right.$ $\mathrm{mL})$ and $\mathrm{Aq}\left(\mathrm{IC}_{50} 84.70 \mu \mathrm{g} / \mathrm{mL}\right)$ in the RAW 264.7 cell line ( $>$ Fig. 3).

As shown in > Fig. 4a, the subplantar injection of CARR induced an oedema that thickened slowly. The oedema size variation follows a polynomial function. In fact, 2 h after CARR injection, the size of the oedema reached a maximum, which indicates an acute inflammation. Treatment with the Aq extract of T. acutifolius $(5 \mathrm{mg} /$ $\mathrm{kg}$ BW) significantly decreased the paw oedema circumference size ( $97.7 \%$ of oedema inhibition). Likewise, the mice treated with the $\mathrm{DCM} / \mathrm{MeOH}$ fraction ( $5 \mathrm{mg} / \mathrm{kg} \mathrm{BW}$ ) showed increased anti-inflammatory activity ( $97.7 \%$ of oedema inhibition) compared to the HEP (89.31\%) and $\mathrm{Aq}$ (89.31\%) fractions when reaching the 5 th hour after the CARR injection. As expected, the IND positive control (5 $\mathrm{mg} / \mathrm{kg}$ ) also caused a significant inhibition of oedema (57.67\%).

Regarding the anti-arthritic activity, the subplantar injection of CFA led the paw to swell gradually for more than 14 days. The curves of the oedema rate versus time could be divided into two phases. In the first phase, the oedema rate of the injected footpad increased and reached a peak during the first 3 days. Thereafter, the swelling slowly subsided until the 7 th day, when the paw began to swell again and peaked in the 2nd week (second phase). The administration of the Aq extract of T. acutifolius ( $5 \mathrm{mg} / \mathrm{kg} \mathrm{BW}$ ) signif-

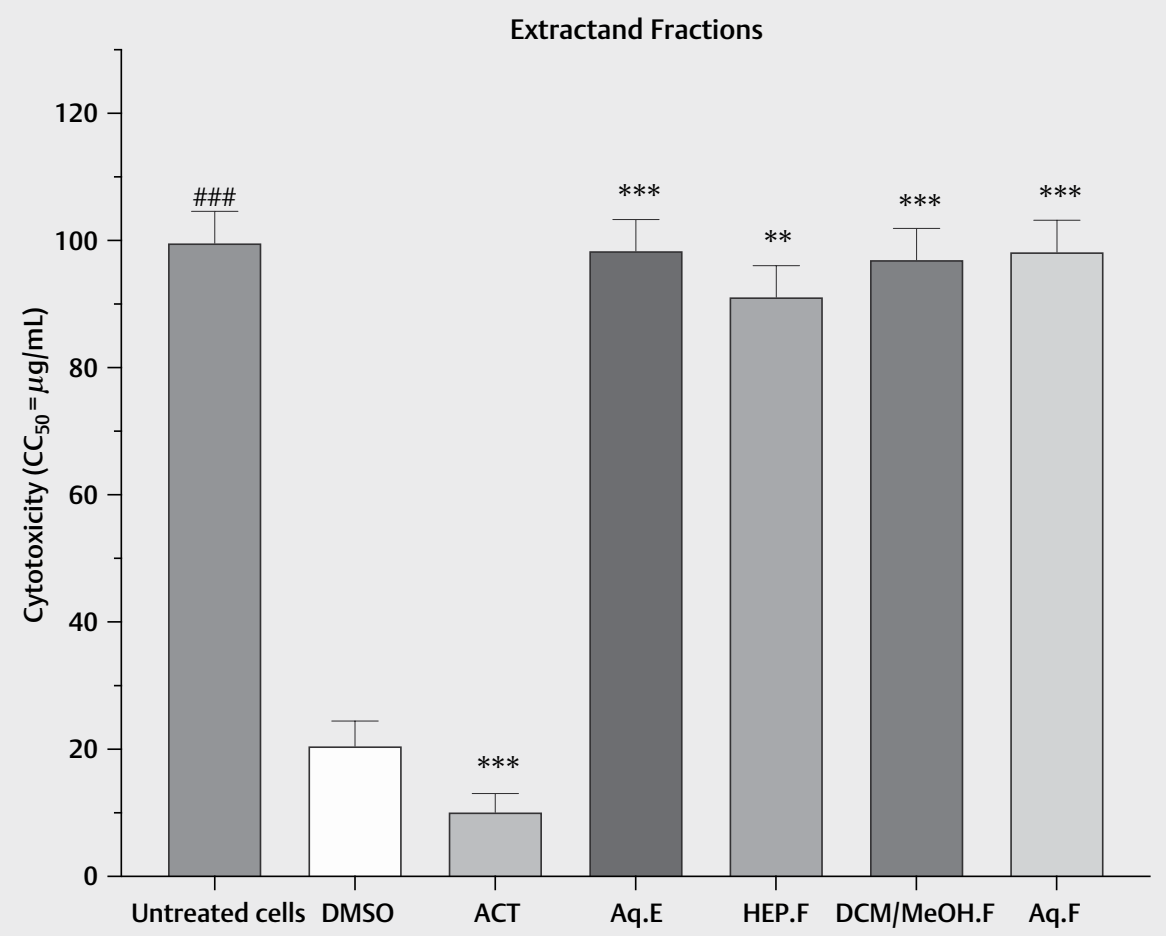

- Fig. $2 \mathrm{CC}_{50}$ values of the LDH (cytotoxicity) assays calculated for the extract (Aq.E) and fractions (HEP.F, DCM/MeOH.F, and Aq.F) from T. acutifolius were calculated with Prism v9.0.0 (GraphPad Software) using nonlinear regression, dose-response curves. CI 95\%: confidence interval $95 \%$ | Tukey's multiple comparisons test. $\left({ }^{* *} \mathrm{p}=0.01,{ }^{* * *} \mathrm{p}=0.001\right.$,\#\#\#) 


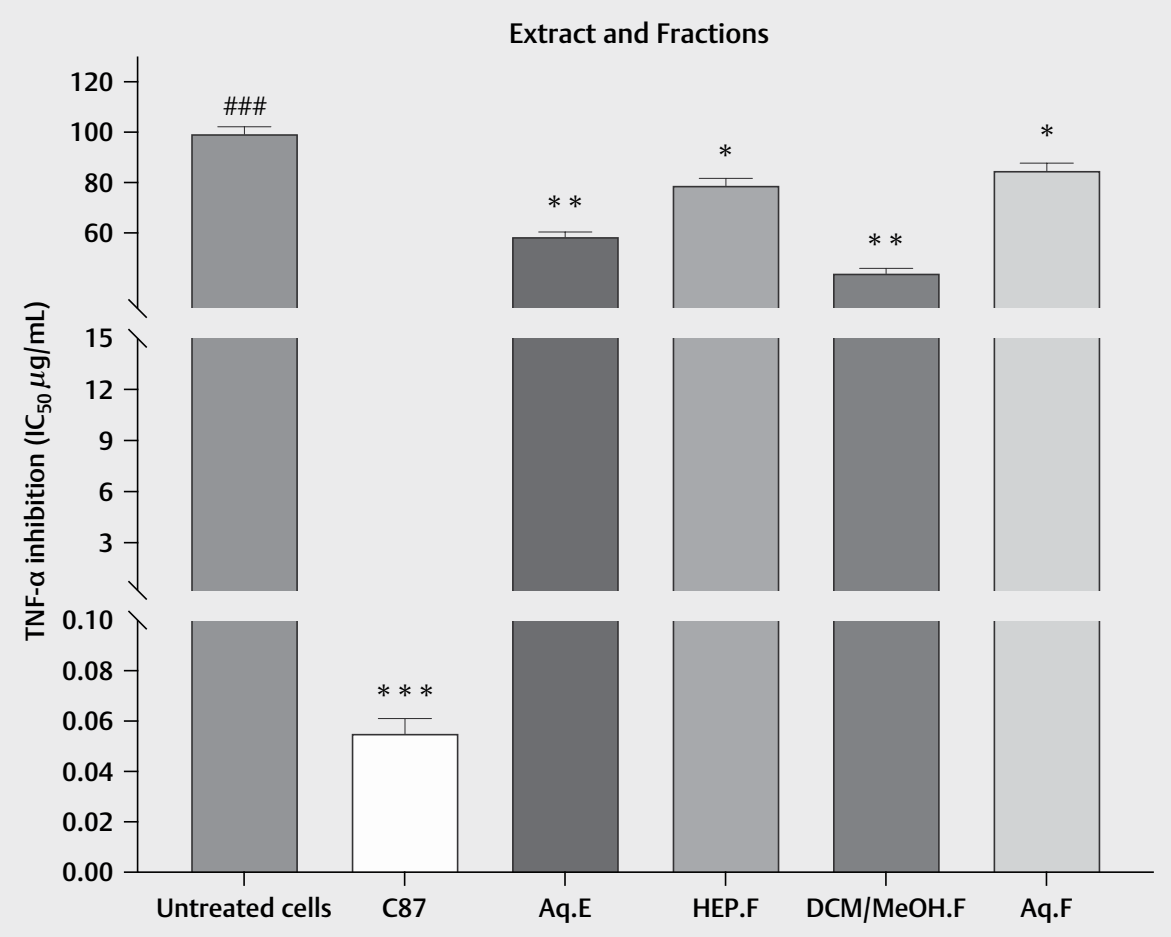

Fig. 3 Comparative study of the extract (Aq.E) and fractions (HEP.F, DCM/MeOH.F, and Aq.F) from T. acutifolius with the C87 positive control on TNF- $\alpha$ inhibition $\left({ }^{*} \mathrm{p}=0.1,{ }^{* *} \mathrm{p}=0.01,{ }^{* * *} \mathrm{p}=0.001\right)$.
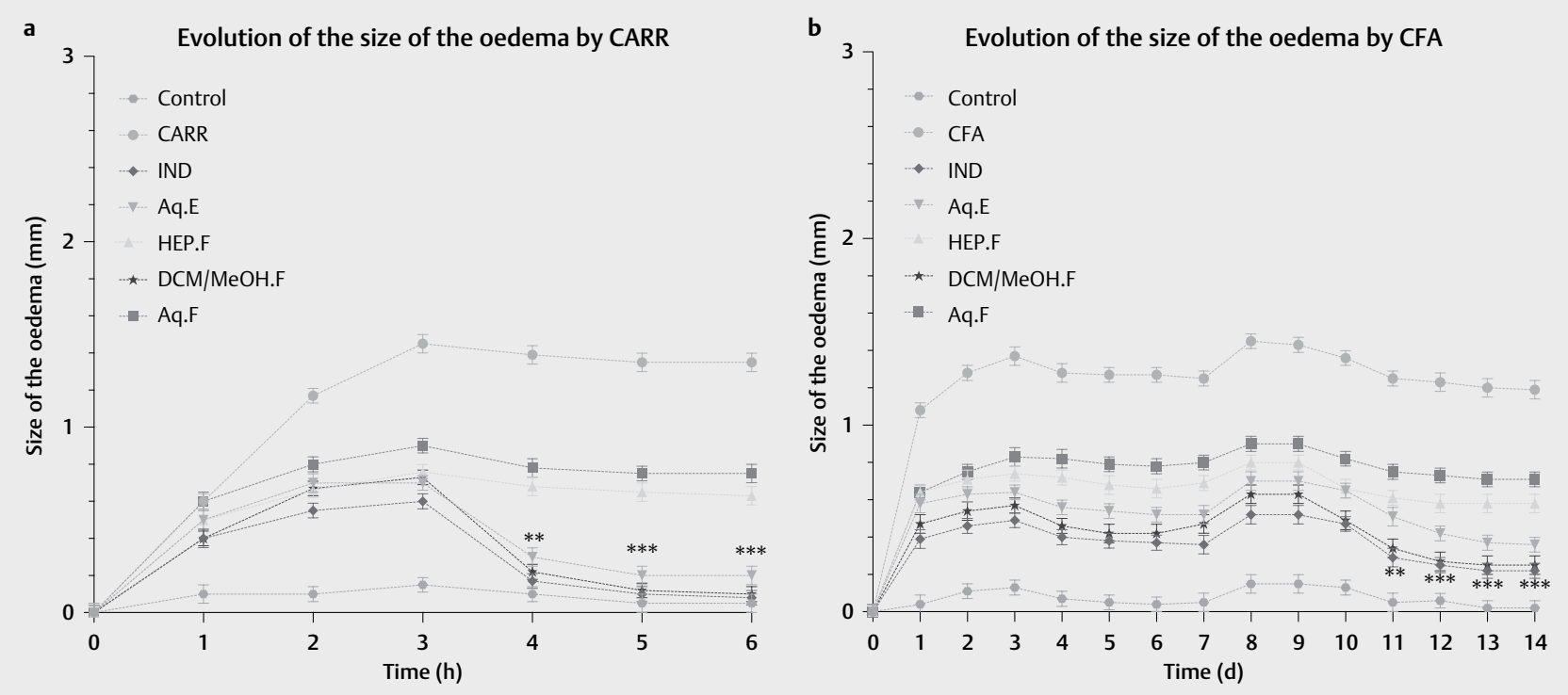

Fig. 4 a, b Oedema size evolution over time in the different groups of mice treated with the extract (Aq.E) and fractions (HEP.F, DCM/MeOH.F, and Aq.F) from T. acutifolius. Controluntreated mice. Each value represents the mean \pm SEM of results from six animals. " * $P<0.01$ and " $\mathrm{p}<0.001$ highly significant difference in comparison with inflamed mice treated with indomethacin (IND group) (one-way ANOVA followed by Tukey's multiple comparisons test).

icantly inhibited the development of joint swelling induced by CFA when compared to the IND positive control $(5 \mathrm{mg} / \mathrm{kg})$ as early as 1 day after CFA injection ( $\vee$ Fig. 4b). Finally, the DCM/MeOH fraction $(5 \mathrm{mg} / \mathrm{kg} \mathrm{BW})$ showed higher anti-arthritic activity ( $97.7 \%$ of oede- ma inhibition) when compared to the HEP (89.31\%) and Aq (89.31\%) fractions during the 1 st day after CFA injection, and this higher potential was maintained until the experiment was terminated on the 14th day. 

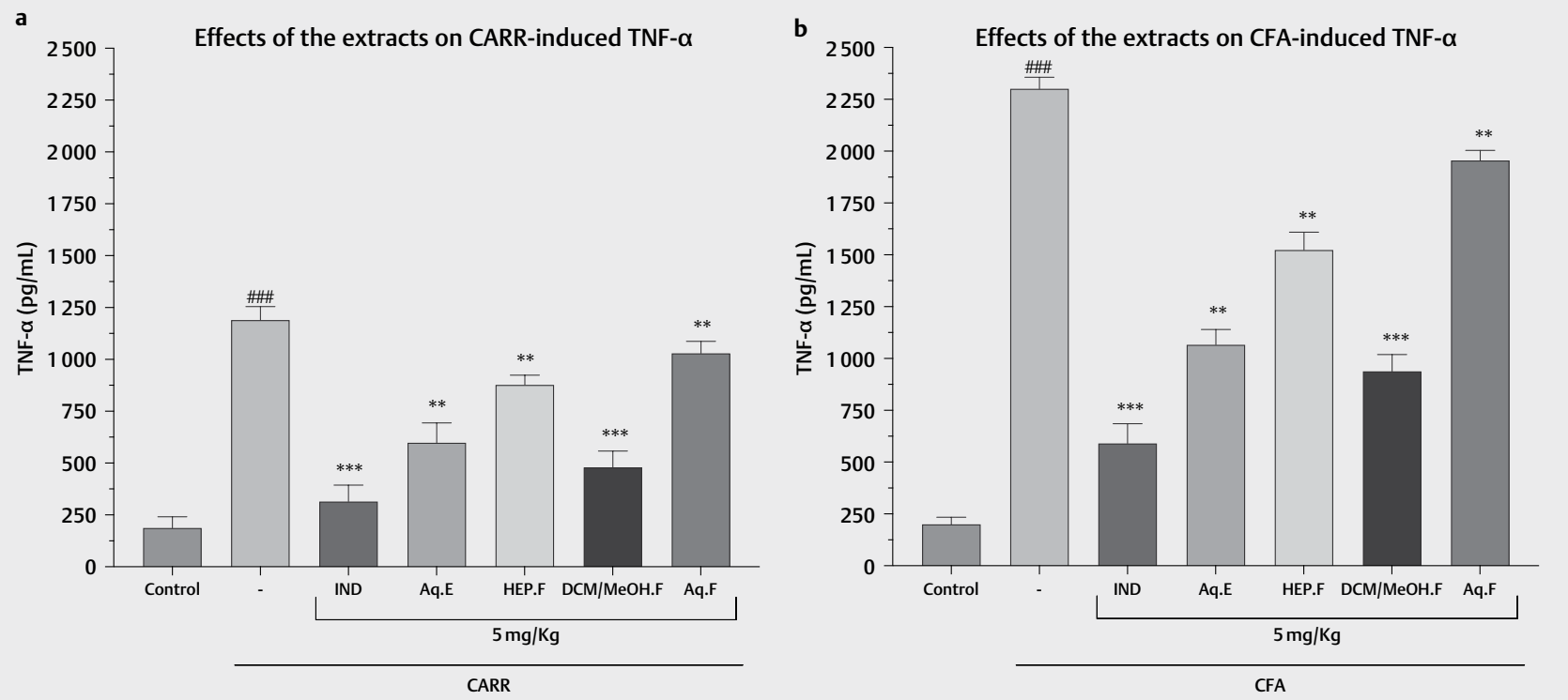

- Fig. 5 a, b The effects of the extract (Aq.E) and fractions (HEP.F, DCM/MeOH.F, and Aq.F) from T. acutifolius on TNF- $\alpha$ induced by CARR and CFA. Controluntreated mice. Each value represents the mean \pm SEM of results from six animals. " $P<0.01$ and ${ }^{* *}$ " $p<0.001$ highly significant difference in comparison with inflamed mice treated with indomethacin (IND group) (one-way ANOVA followed by Tukey's multiple comparisons test).

The subplantar injection of CARR led to a significant increase in the TNF- $\alpha$ level in serum when reaching the 5 th hour $\left({ }^{* * *} \mathrm{p}<0.001\right)$. However, the Aq extract of T. acutifolius $(5 \mathrm{mg} / \mathrm{kg}$ ) decreased the TNF- $\alpha$ level in serum when reaching the 5 th hour after CARR injection $\left({ }^{* * *} \mathrm{p}<0.001\right)$ when compared to the IND group $(5 \mathrm{mg} / \mathrm{kg})$ ( $\vee$ Fig. 5a). However, the subplantar injection of CFA led to a significantly higher increase in the TNF- $\alpha$ level in serum during the first 3 days $\left({ }^{* * *} \mathrm{p}<0.001\right)$. Yet, the Aq extract of $T$. acutifolius $(5 \mathrm{mg} / \mathrm{kg})$ decreased the TNF- $\alpha$ level in serum during the 1st day after the CFA injection ( $\left.{ }^{* * *} \mathrm{p}<0.001\right)$ when compared to the IND group (5 mg/ kg) ( Fig. 5b).

Regarding the CRP level and the fibrinogen rate, a highly significant increase was observed in the CARR group when compared to the control group ( $\left.{ }^{* * *} \mathrm{p}<0.001\right)$. Yet, the CRP level significantly decreased $\left({ }^{* * *} \mathrm{p}<0.001\right)$ in the groups treated with the Aq extract of T. acutifolius $(11.77 \mathrm{mg} / \mathrm{mL}$ ), with the DCM/MeOH fraction $(9.72$ $\mathrm{mg} / \mathrm{mL})$, and IND $(12.94 \mathrm{mg} / \mathrm{mL})$ when compared to the CARR group $(23.34 \mathrm{mg} / \mathrm{mL})$ ( $\mathbf{F i g . ~ 6 a )}$. Also, the fibrinogen rate decreased significantly ( $\left.{ }^{* * *} \mathrm{p}<0.001\right)$ in the groups treated with the Aq extract of $T$. acutifolius $(4.08 \mathrm{~g} / \mathrm{L})$, with the DCM/MeOH fraction $(3.76 \mathrm{~g} / \mathrm{L})$, and IND $(3.31 \mathrm{~g} / \mathrm{L})$ when compared to the CARR group $(5.70 \mathrm{~g} / \mathrm{L})(\triangleright$ Fig. 6 b).

Finally, when compared to the control group, a highly significant increase was observed in the CFA group $\left({ }^{* * *} \mathrm{p}<0.001\right)$ regarding the CRP level and fibrinogen rate. Yet, in the groups treated with the Aq extract of T. acutifolius (21.50 mg/mL), with the DCM/MeOH fraction $(19.45 \mathrm{mg} / \mathrm{mL})$, and IND $(25.04 \mathrm{mg} / \mathrm{mL})$, the CRP levels decreased significantly $\left({ }^{* * *} \mathrm{p}<0.001\right)$ when compared to the CFA group $(33.07 \mathrm{mg} / \mathrm{mL}$ ) (> Fig. 7a).

Moreover, the fibrinogen rate decreased significantly $\left({ }^{* * *} \mathrm{p}<0.001\right)$ in the groups treated with the Aq extract of T. acuti- folius $(13.81 \mathrm{~g} / \mathrm{L})$, with the DCM/MeOH fraction $(13.49 \mathrm{~g} / \mathrm{L})$, and IND $(13.04 \mathrm{~g} / \mathrm{L})$ when compared to the CFA group $(15.43 \mathrm{~g} / \mathrm{L})$ ( Fig. 7b).

(E)-2',4'-Dihydroxy-6'-methoxy-chalcone (1), 6,2',4'-trimethoxyflavone (2), 5,3',4'-trihydroxy-6,7,8-trimethoxyflavone (3), and 5,4'-dihydroxy-6,7,8-trimethoxyflavone (4) exhibited a cytotoxic effect through the LDH assay, with CC $_{50}$ values of 56.50, 59.80, 89.20, and $92.01 \mu \mathrm{M}$, respectively, in the RAW 264.7 cell line ( $\triangleright$ Fig. 8).

Based on the results obtained, only compounds 1 and $\mathbf{2}$ cause a loss of cell membrane integrity, causing necrosis of RAW 264.7 cells $[34,35]$. The cLogP of compounds $\mathbf{1}, \mathbf{2}, \mathbf{3}$, and $\mathbf{4}$ were 3.62 , $3.54,1.54$, and 1.23 , respectively. CLogP is a measure that determines the lipophilic ability of compounds to cross cell membranes. The fact that this value is greater than 1 means that the compounds have a greater affinity for the octanol phase than for the aqueous phase and, by extension, the compounds will tend to move through the epidermal lipid layer. The penetration of the more lipophilic compounds will generate a greater concentration of them within the cell, which can generate cytotoxicity.

Analysing the cLogP of the compounds, a relationship between lipophilicity and cytotoxicity was observed, and this is justified by the fact that increases in lipophilicity lead to higher cytotoxicity of the compounds.

The flavonoids (E)-2',4'-dihydroxy-6'-methoxy-chalcone (1), 6,2',4'-trimethoxyflavone (2), 5,3',4'-trihydroxy-6,7,8-trimethoxyflavone (3), and 5,4'-dihydroxy-6,7,8-trimethoxyflavone (4) inhibited the production of TNF- $\alpha$ in the RAW 264.7 cell line, with $\mathrm{IC}_{50}$ values of $0.78,1.43,5.73$, and $9.71 \mu \mathrm{M}$, respectively ( $>$ Fig. 9).

Previous studies indicated that compound 1 inhibited TNF- $\alpha$ production in B16-F10 $\left(\mathrm{IC}_{50} 0.60 \mu \mathrm{M}\right)$, THP-1 $\left(\mathrm{IC}_{50} 1.12 \mu \mathrm{M}\right)$, and RAW $264.7\left(\mathrm{IC}_{50} 4.6 \mu \mathrm{M}\right)$ cells [33-36]. Regarding compounds 2, 3, 

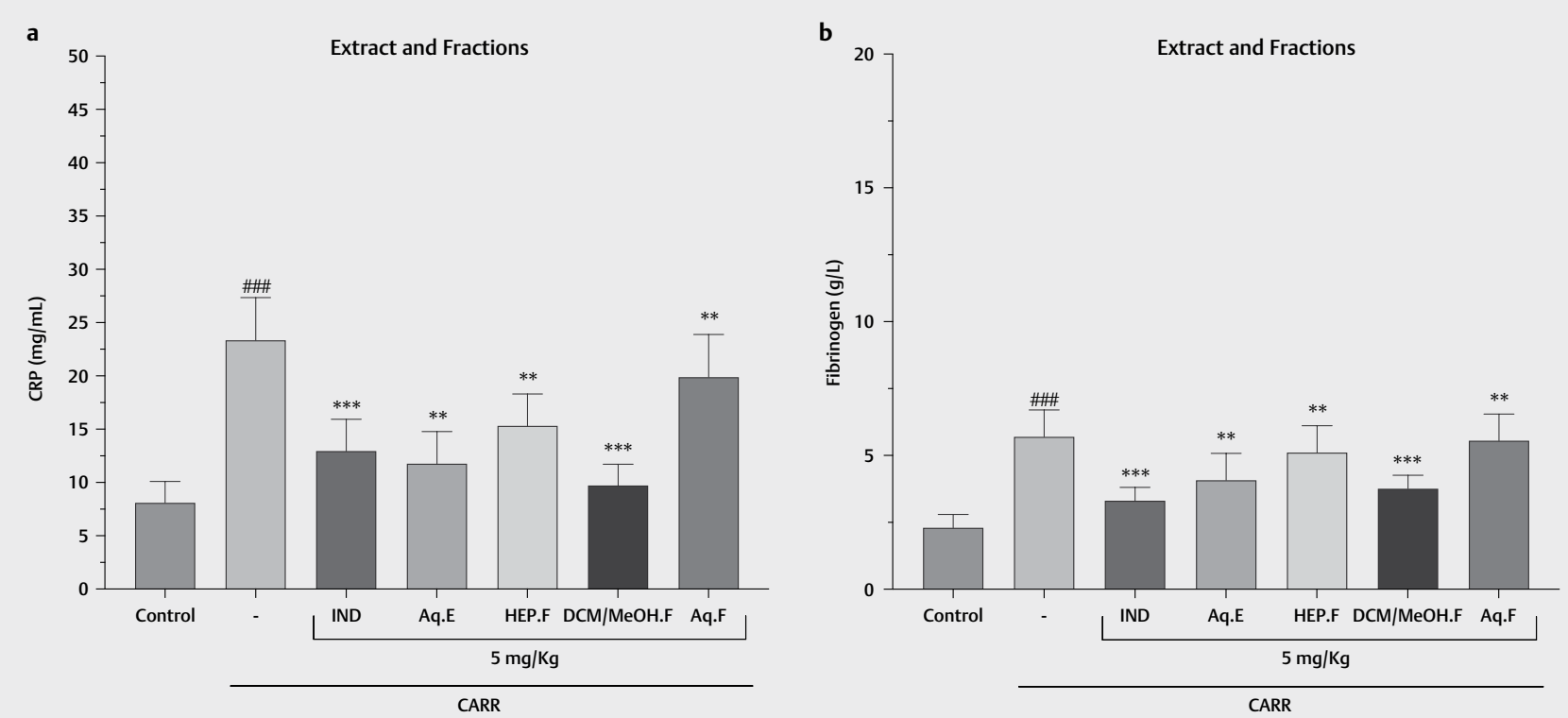

- Fig. 6 a, b Study of CRP levels and fibrinogen in mice treated with the extract (Aq.E) and fractions (HEP.F, DCM/MeOH.F, and Aq.F) from T. acutifolius induced by CARR. Values represent the mean $\pm S D(n=6)$ in each group.
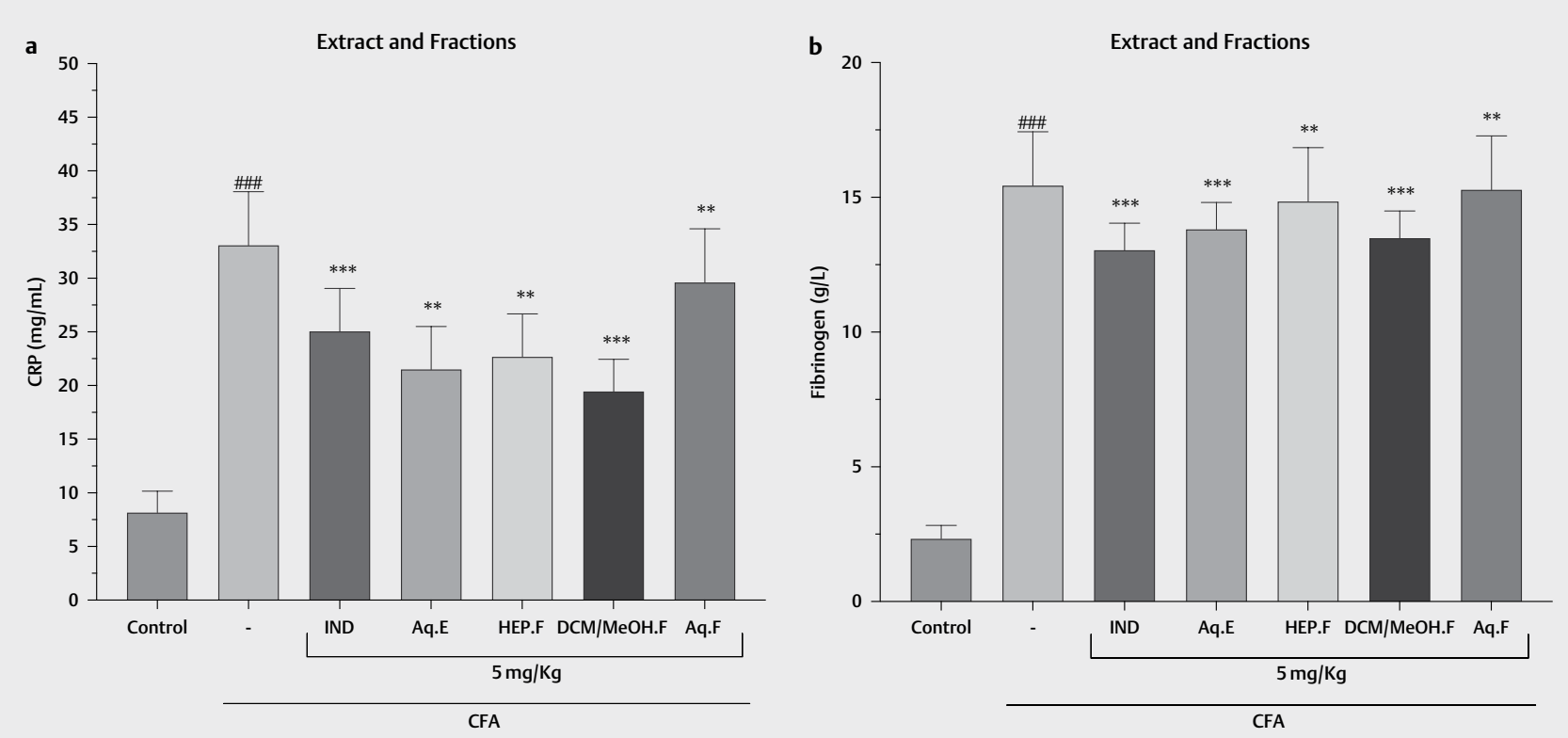

- Fig. 7 a, b Study of CRP levels and fibrinogen in mice treated with the extract (Aq.E) and fractions (HEP.F, DCM/MeOH.F, and Aq.F) from T. acutifolius induced by CFA. Values represent the mean $\pm S D(n=6)$ in each group.

and 4, they inhibited the production of TNF- $\alpha$ with IC 50 values of $1.32,5.63$, and $3.77 \mu \mathrm{M}$, respectively, for B16-F10 cells and 2.38, 12.36, and $8.09 \mu \mathrm{M}$, respectively, for THP-1 cells [33].

Our study confirms that compounds 1 and $\mathbf{2}$ have higher biological activity (inhibition of TNF- $\alpha$ production) than compounds 3 and 4. This effect is due to the lipophilic capacity of compounds 1 and $\mathbf{2}$. However, the smaller TNF- $\alpha$ inhibition potential of com- pounds $\mathbf{3}$ and $\mathbf{4}$ is due to the degree of hydroxylation, with com-

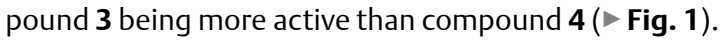

All flavonoids decreased the TNF- $\alpha$ level in serum when reaching the 5 th hour after the CARR injection $\left({ }^{* * *} \mathrm{p}<0.001\right)$. Nevertheless, (E)-2',4'-dihydroxy-6'-methoxy-chalcone (1) and 6,2',4'-trimethoxyflavone (2) showed a higher decrease in the TNF- $\alpha$ level in serum when reaching the 5 th hour after the CARR injection $\left({ }^{* * *} \mathrm{p}<0.001\right)$ when compared to the IND group ( $5 \mathrm{mg} / \mathrm{kg}$ ) ( $\mathbf{F i g}$. 10a). Additionally, all 


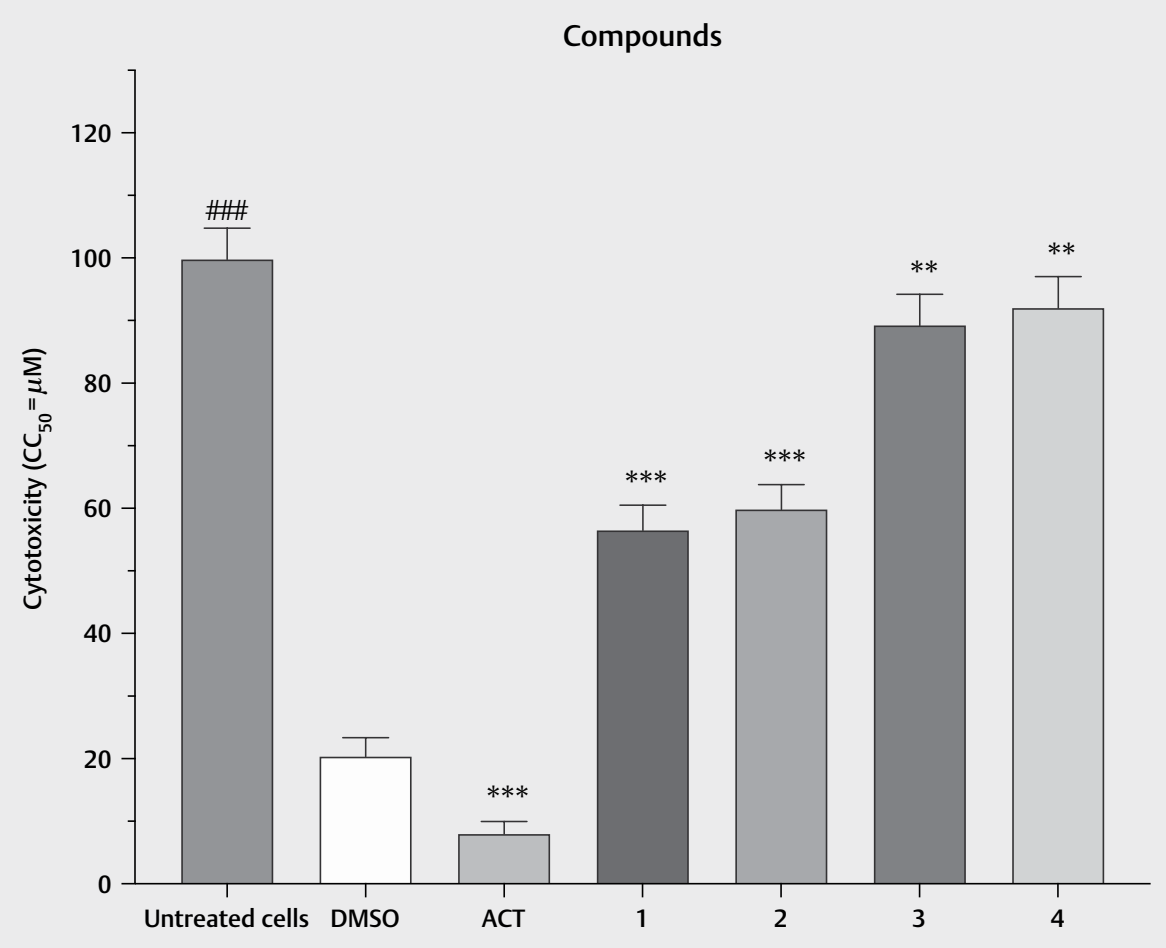

> Fig. $8 \mathrm{CC}_{50}$ values of the LDH (cytotoxicity) assays calculated for the compounds (E)-2',4'-dihydroxy-6'-methoxy-chalcone (1), 6,2',4'-trimethoxyflavone (2), 5,3',4'-trihydroxy-6,7,8-trimethoxyflavone (3), and 5,4'-dihydroxy-6,7,8-trimethoxyflavone (4) from T. acutifolius. CC 50 values were calculated with Prism v9.0.0 (GraphPad Software) using nonlinear regression, dose-response curves. CI 95\%: confidence interval $95 \% / T u k e y$ 's multiple comparisons test ( " $\mathrm{p}<0.01$ and ${ }^{* *}$ " $\mathrm{p}<0.001$ ).

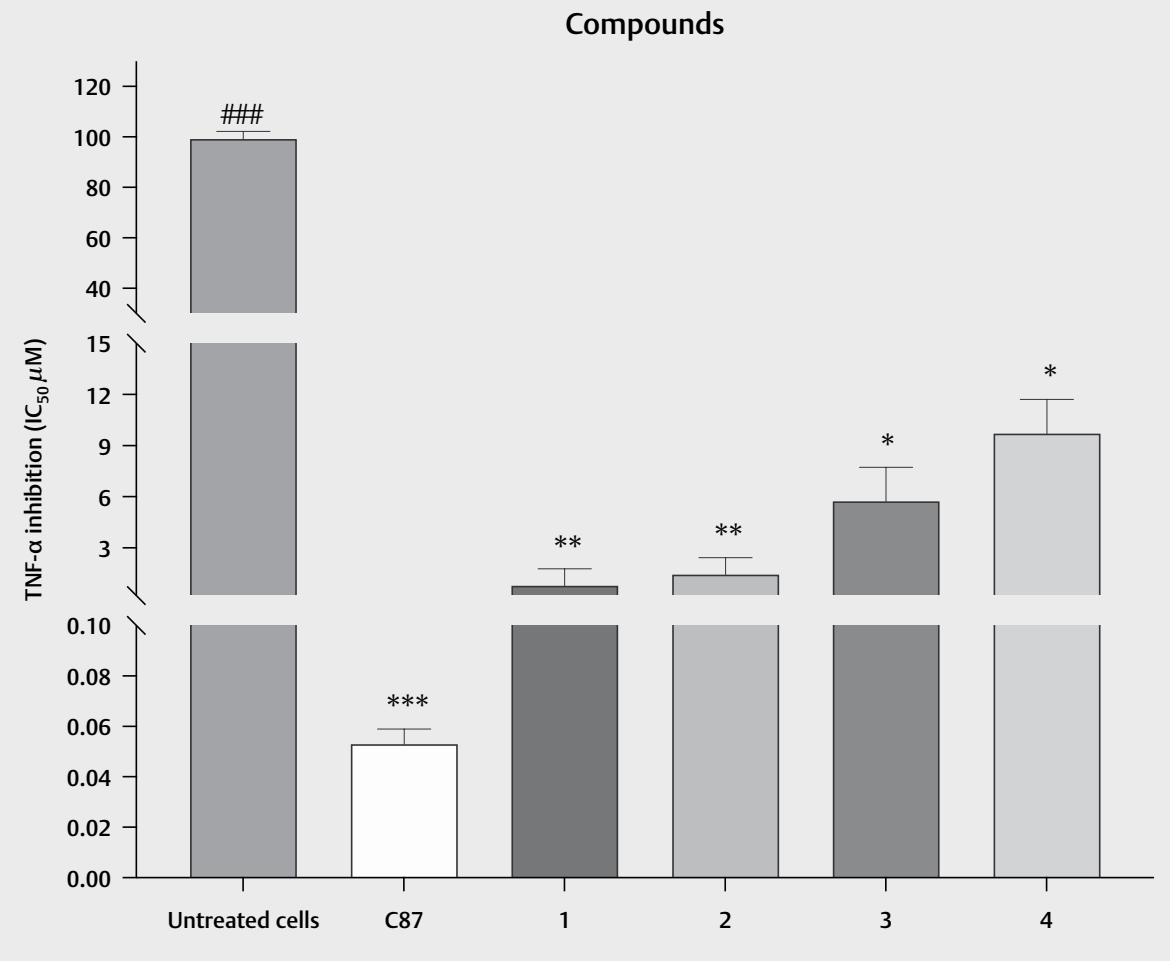

- Fig. 9 Comparative study of the compounds (E)-2',4'-dihydroxy-6'-methoxy-chalcone (1), 6,2', 4'-trimethoxyflavone (2), 5,3',4'-trihydroxy-6,7,8trimethoxyflavone (3), and 5,4'-dihydroxy-6,7,8-trimethoxyflavone (4) from T. acutifolius with the C87 positive control on TNF- $\alpha$ inhibition. 
flavonoids ( $5 \mathrm{mg} / \mathrm{kg}$ ) decreased the TNF- $\alpha$ level in serum during the first 3 days after the CFA injection ( $\left.{ }^{* * *} \mathrm{p}<0.001\right)$. Yet, $(E)-2^{\prime}, 4^{\prime}$-dihydroxy-6'-methoxy-chalcone (1) and 6,2',4'-trimethoxyflavone (2) decreased the TNF- $\alpha$ level in serum after the 1 st day following the injection of CFA $\left({ }^{* * *} \mathrm{p}<0.001\right)$ when compared to the IND group $(5 \mathrm{mg} /$ $\mathrm{kg})$ ( Fig. 10b).

Regarding compound $\mathbf{1}$, our results are comparable to those described by Takahashi et al. [37], who mention that compound 1 decreased TNF- $\alpha$ levels in murine model assays at concentrations between $0.02-2 \mathrm{mg} / \mathrm{kg}$ BW.

The CARR and CFA assays have long been accepted as useful tools to investigate the development of new drugs with anti-inflammatory and anti-arthritic activity [38]. Recent studies revealed that cytokine production plays an essential role in the development of RA [39]. The complicated network of cytokines involved in RA is formed by mutual regulation in the synthesis and secretion of various cytokines, with TNF- $\alpha$ being the most representative cytokine that exerts a synergistic effect and facilitates the immune pathological process of RA [40,41].

Statistical analysis revealed that compounds $\mathbf{1}$ and $\mathbf{2}$ and IND significantly inhibited the development of oedema when reaching the 5 th hour after treatment $\left({ }^{* * *} \mathrm{p}<0.001\right)$. Both showed anti-inflammatory effects on the paw of mice with CARR-induced oedema. Likewise, compounds 1 and 2 and IND significantly ( $\left.{ }^{* * *} \mathrm{p}<0.001\right)$ inhibited the development of oedema in the first 3 days after the injection with CFA in the paws of mice.

Analysing the anti-inflammatory action that many flavonoids possess, we observed that they are related to the inhibition of various enzymes involved in the inflammatory process. Polyhydroxylated flavonoids have been reported to act preferentially via the 5-lipoxygenase pathway in in vitro assays, while the less hydroxylated ones fundamentally inhibit the cyclooxygenase pathway. However, in in vivo assays, there are reports that they behave as dual inhibitors of both pathways. This difference in behaviour, not exclusive to flavonoids, is due to the biotransformation (methoxylation) they undergo in the body [42].

In our case, we observed that the anti-inflammatory activity of flavonoids not only depends on the degree of hydroxylation, but also on the lipophilic capacity. Our results show that compound 1 has a greater in vitro and in vivo anti-inflammatory effect when compared to compounds 2, 3, and $\mathbf{4}$ due to its lipophilic capacity (cLogP3.62), degree of hydroxylation (presence of 2 hydroxyl groups), and chemical structure (open ring $\mathrm{C}$ ). However, when we compare the anti-inflammatory activity of compound $\mathbf{2}$ with compounds $\mathbf{3}$ and $\mathbf{4}$, we observe that the activity of compound $\mathbf{2}$ is mainly due to its lipophilic capacity (cLogP3.54), since it does not have hydroxyl groups. Finally, in relation to compounds 3 and $\mathbf{4}$, we observed that there is a correlation between the lipophilic capacity and the degree of hydroxylation, with compound 3 being more active than compound $\mathbf{4}$.

In relation to the CRP level, this decreased significantly $\left({ }^{* * *} \mathrm{p}<0.001\right)$ in the groups treated with $(E)-2$ ', 4'-dihydroxy-6'methoxy-chalcone (8.12 mg/mL), 6,2',4'-trimethoxyflavone (10.17 $\mathrm{mg} / \mathrm{mL})$, and IND $(12.85 \mathrm{mg} / \mathrm{mL})$ compared to the CARR group $(23.37 \mathrm{mg} / \mathrm{mL})$ ( Fig. 11a). Lastly, with respect to the fibrinogen rate, this decreased significantly $\left({ }^{* * *} \mathrm{p}<0.001\right)$ in the groups treated with $(E)-2$ ', 4'-dihydroxy-6'-methoxy-chalcone $(2.36 \mathrm{~g} / \mathrm{L})$, 6,2',4'-trimethoxyflavone (2.68 g/L), and IND (3.34 g/L) when compared to the CARR group ( $5.67 \mathrm{~g} / \mathrm{L})$ ( $\vee$ Fig. 11b).

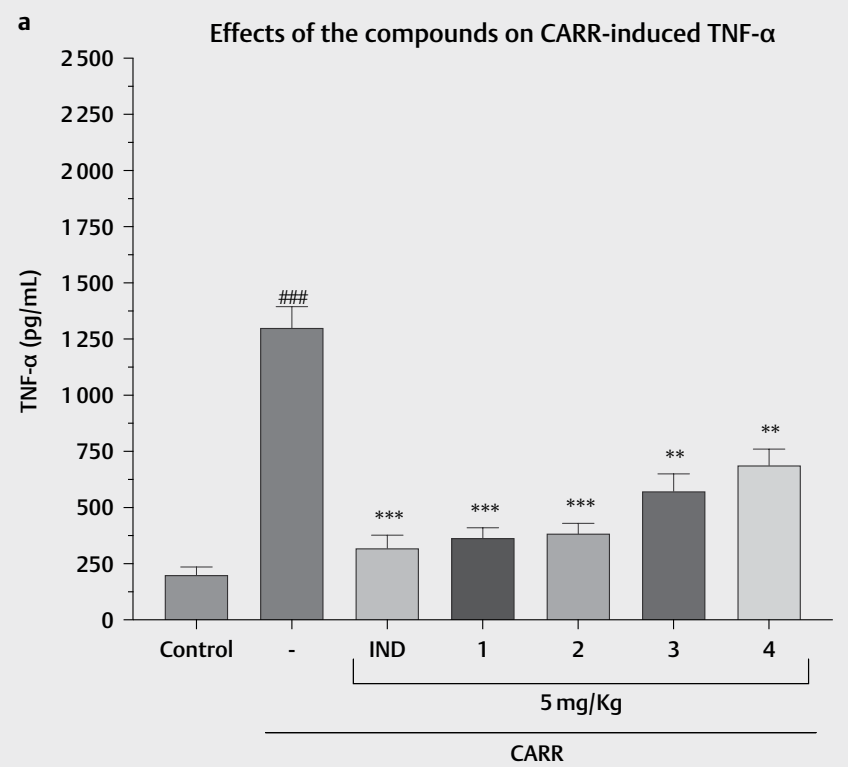

b

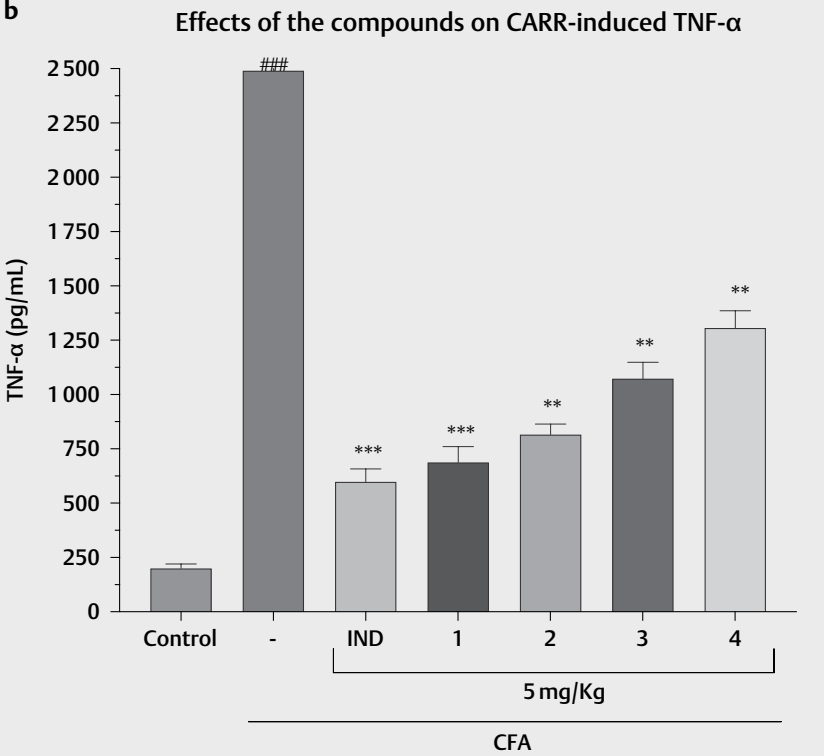

- Fig. 10 a, b The effects of compounds (E)-2',4'-dihydroxy-6'-methoxy-chalcone (1), 6,2',4'-trimethoxyflavone (2), 5,3',4'-trihydroxy-6,7,8-trimethoxyflavone (3), and 5,4'-dihydroxy-6,7,8-trimethoxyflavone (4) from T. acutifolius on TNF- $\alpha$ induced by CARR and CFA. Control (untreated control mice). Each value represents the mean \pm SEM of results from six animals. ${ }^{* *} \mathrm{P}<0.01$ and ${ }^{* *}{ }^{*} \mathrm{p}<0.001$ highly significant difference in comparison with inflamed mice treated with indomethacin (IND group) (one-way ANOVA followed by Tukey’s multiple comparisons test). 

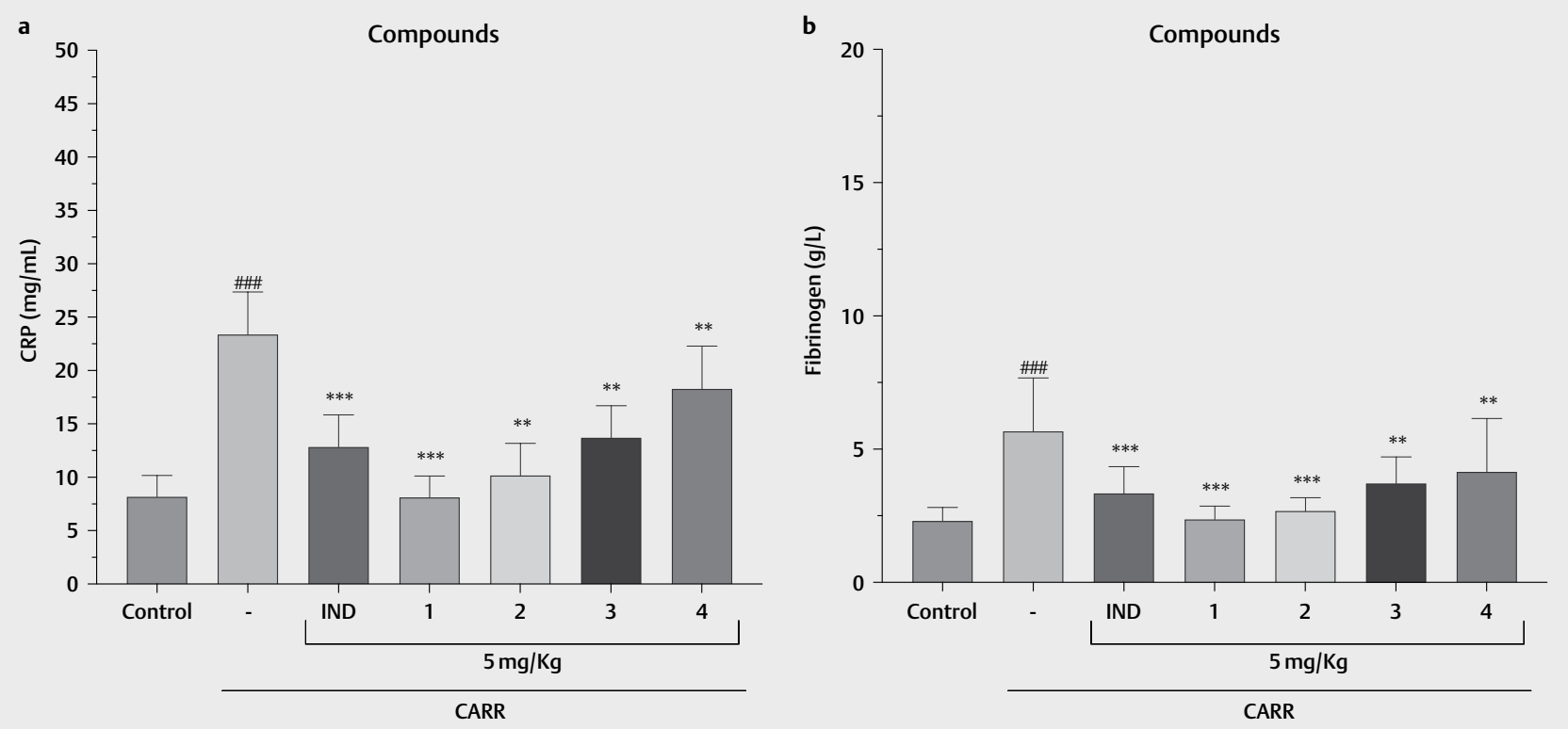

- Fig. 11 a, b Study of CRP levels and fibrinogen in mice treated with the compounds (E)-2',4'-dihydroxy-6'-methoxy-chalcone (1), 6,2',4'-trimethoxyflavone (2), 5,3',4'-trihydroxy-6,7,8-trimethoxyflavone (3), and 5,4'-dihydroxy-6,7,8-trimethoxyflavone (4) from T. acutifolius by CARR. Values represent the mean $\pm S D(n=6)$ in each group.

On the other hand, the CRP level decreased significantly $\left({ }^{* * *} \mathrm{p}<0.001\right)$ in the groups treated with $(E)-2$ ', 4'-dihydroxy-6'methoxy-chalcone (14.86 mg/mL), 6,2',4'-trimethoxyflavone $(16.91 \mathrm{mg} / \mathrm{mL})$, and IND $(25.12 \mathrm{mg} / \mathrm{mL})$ when compared to the CFA group $(33.95 \mathrm{mg} / \mathrm{mL}$ ) ( Fig. 12a). Finally, with respect to the fibrinogen rate, this decreased significantly $\left({ }^{* * *} \mathrm{p}<0.001\right)$ in the groups treated with $(E)-2$ ', 4'-dihydroxy-6'-methoxy-chalcone (11.19 g/L), 6,2',4'-trimethoxyflavone (11.51 g/L), and IND (13.07 $\mathrm{g} / \mathrm{L}$ ) when compared to the CFA group (15.64 g/L) ( $>$ Fig. 12b).

Haematological changes that occur after the administration of CARR or CFA confirm the resulting acute or chronic inflammation. These changes led to an impressive increase in blood cells and platelets at the site of inflammation due to the release of inflammatory cytokines. Likewise, the inhibition of inflammation in the mice treated with the compounds $(5 \mathrm{mg} / \mathrm{kg}$ ) was confirmed by the significant decrease in fibrinogen and CRP levels compared to mice treated with the synthetic drug (IND).

In conclusion, we found that in assays of short duration, such as CARR-induced oedema, as well as in assays of longer duration, such as CFA-induced arthritis, the Aq extract from T. acutifolius at a concentration of $5 \mathrm{mg} / \mathrm{kg}$ significantly inhibited the swelling of the mice feet. These results suggest that this plant has anti-inflammatory effects on acute experimental arthritis.

Likewise, compounds (E)-2',4'-dihydroxy-6'-methoxy-chalcone (1), 6,2',4'-trimethoxyflavone (2), 5,3',4'-trihydroxy-6,7,8-trimethoxyflavone (3), and 5,4'-dihydroxy-6,7,8-trimethoxyflavone (4) isolated from $T$. acutifolius have a potent suppressive effect in proinflammatory responses, proving to be an alternative for the treatment of inflammatory diseases. Among the four compounds, the chalcone appears as the most promising compound in terms of pharmacological activity, and this is due to the fact that it misses the $C$ ring.

Similarly, our results support the traditional use of $T$. acutifolius as an anti-inflammatory treatment, showing evidence that the compounds isolated from the Aq extract inhibit the production of the TNF- $\alpha$ cytokine. In this sense, our study contributes towards the discovery of compounds capable of modulating the activities of TNF- $\alpha$.

\section{Materials and Methods}

\section{Plant material}

The leaves of $T$. acutifolius were collected from the Titicani-Tacaca community, Ingavi province, La Paz, Bolivia (16²4’45.6"S 68 51’04.5"W), in July 2018 , at an altitude of $3901 \mathrm{~m}$. The botanical identification was confirmed by the National Herbarium of Bolivia (No. 12779).

\section{General experimental procedures}

TLC was performed using Merck silica gel 60-F254 plates. The chromatograms thus obtained were visualised by UV absorbance ( 254 $\mathrm{nm}$ ) and through heating a plate stained with $5 \%$ of phosphomolybdic acid $\left(\mathrm{H}_{3} \mathrm{PMo}_{12} \mathrm{O}_{40}\right)$. Open column chromatography was performed with silica gel (20-45 and 40-63 $\mu \mathrm{m})$, and the indicated eluent was in accordance with standard techniques.

NMR experiments were performed on a Bruker Analytische Messtechnik $\mathrm{GmbH}$ spectrometer operating at $500 \mathrm{MHz}\left({ }^{1} \mathrm{H}\right)$ or $125 \mathrm{MHz}\left({ }^{13} \mathrm{C}\right)$ and a Bruker BioSpin $\mathrm{GmbH}$ operating at $700 \mathrm{MHz}$ $\left({ }^{1} \mathrm{H}\right)$ or $175 \mathrm{MHz}\left({ }^{13} \mathrm{C}\right)$. The deuterated solvents were MeOD- $\mathrm{d}_{4}, \mathrm{CD}$ $\mathrm{Cl}_{3}-\mathrm{d}_{1}$ and $\mathrm{D}_{2} \mathrm{O}-\mathrm{d}_{2}$. Spectra were calibrated by the assignment of 

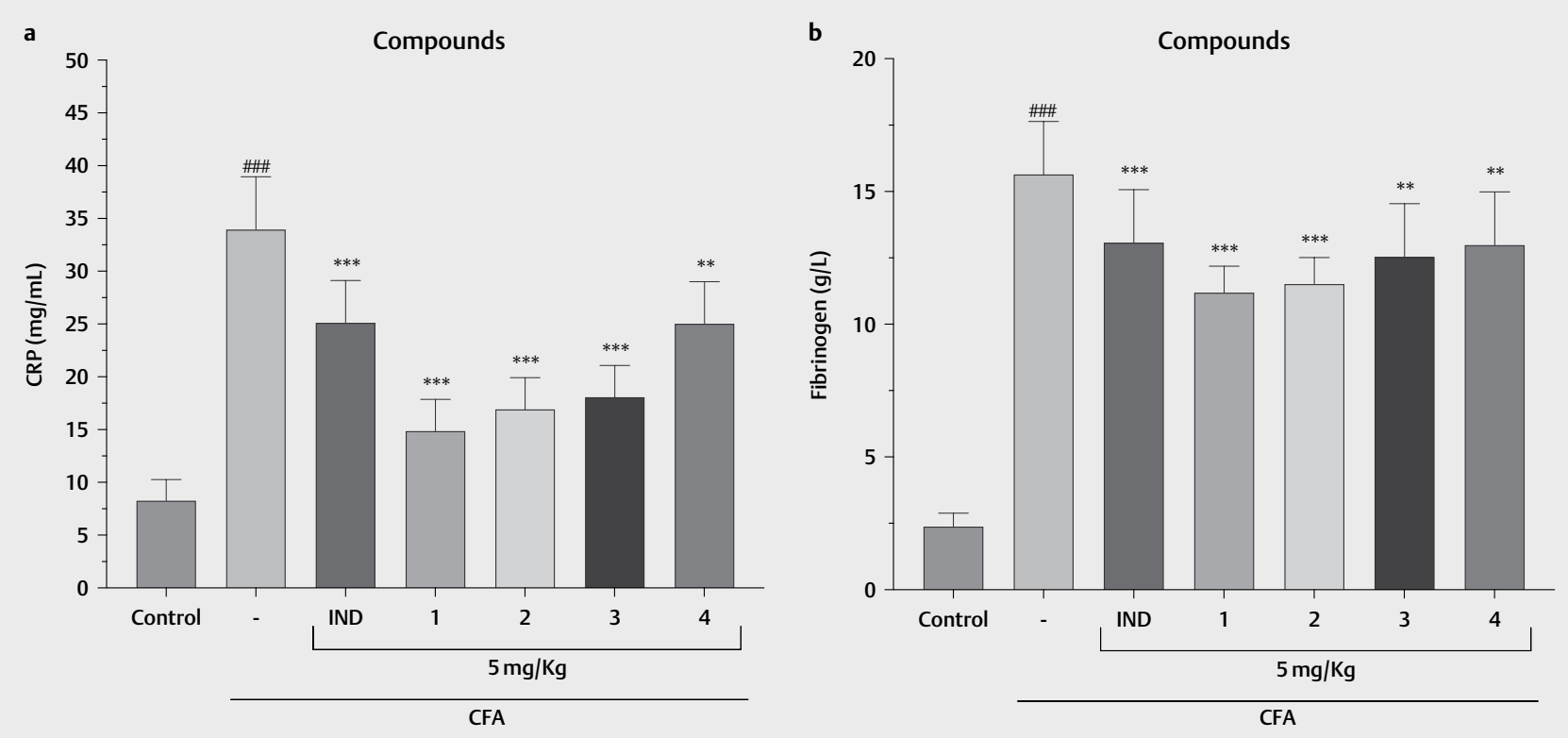

- Fig. 12 a, b Study of CRP levels and fibrinogen in mice treated with the compounds (E)-2',4'-dihydroxy-6'-methoxy-chalcone (1), 6,2',4'-trimethoxyflavone (2), 5,3',4'-trihydroxy-6,7,8-trimethoxyflavone (3), and 5,4'-dihydroxy-6,7,8-trimethoxyflavone (4) from T. acutifolius by CFA. Values represent the mean $\pm S D(n=6)$ in each group.

the residual solvent peak to $\delta_{\mathrm{H}} 7.26 \mathrm{ppm}$ and $\delta_{\mathrm{C}} 77.16 \mathrm{ppm}$ for $\mathrm{CDCl}_{3}-\mathrm{d}_{1}, \delta_{\mathrm{H}} 3.31 \mathrm{ppm}$ and $\delta_{\mathrm{c}} 49.0 \mathrm{ppm}$ for MeOD- $\mathrm{d}_{4}$ and $\delta_{\mathrm{H}} 4.79 \mathrm{ppm}$ for $D_{2} O-d_{2}$. The complete assignment of protons and carbons was done by analysing the correlated ${ }^{1} \mathrm{H}-{ }^{-1} \mathrm{H}$ COSY, HSQC and HMBC spectra. HREIMS analyses were performed using a QSTAR XL quadrupole TOFMS. MS samples were prepared in $\mathrm{MeOH}$.

\section{Preparation of aqueous extract of Tripodanthus acutifolius and isolation of compounds}

Air-dried leaves ( $500 \mathrm{~g}$ ) were extracted by decoction (30 min with boiling $\mathrm{DH}_{2} \mathrm{O} ; 500 \mathrm{~g}$ ). The resulting Aq solution was placed in glass containers weighing approximately $100 \mathrm{~g}$ per tray. The glass containers were placed in a lyophilisation tunnel for their respective drying for a period of 2-3 $\mathrm{h}$ at a pressure of $0.3-1$ torr with an initial temperature of $25^{\circ} \mathrm{C}$ until reaching a temperature of $60^{\circ} \mathrm{C}$ (approximately).

Subsequently, the Aq extract $(240 \mathrm{~g}$ ) was further extracted with HEP, DCM/MeOH, (1:1) and $\mathrm{DH}_{2} \mathrm{O}$. As a result, three fractions of 15,70 , and $135 \mathrm{~g}$, respectively, were obtained. Each fraction was evaluated for its cytotoxicity and anti-inflammatory activities.

The DCM/MeOH fraction ( $50 \mathrm{~g}$ ) was selected as the most active one and was fractionated using a chromatographic column (silica gel; $40-63 \mu \mathrm{m})$ using a step gradient of HEP/ACOEt $(7: 1 \rightarrow 3: 1)$ to produce 13 fractions (I-XIII). Fractions $\mathbf{X}(2.5 \mathrm{~g}), \mathbf{X I}(3.7 \mathrm{~g})$, and XII $(2.8 \mathrm{~g})$ were observed to be the most active (anti-inflammatory activity).

The chromatographic profile analysis of these fractions (X, XI, and XII) showed that they were similar, therefore they were pooled. A second chromatographic column (silica gel; $20-45 \mu \mathrm{m}$ ) was performed using a step gradient HEP/AcOEt $(3: 0 \rightarrow 0: 3)$. Ten fractions
(1-10) were obtained. All ten fractions showed anti-inflammatory activity, but fractions $\mathbf{2}, \mathbf{5}, \mathbf{8}$, and $\mathbf{9}$ were the most active.

The analysis of the chromatographic profile of fractions $\mathbf{2 , 5 , 8}$, and 9 showed that they were pure (>99\%). They were identified as (E)-2'4'-dihydroxy-6'-methoxy-chalcone (1 g) (1), 2',4',6-trimethoxyflavone (0.93 g) (2), 3',4',5-trihydroxy-6,7,8-trimethoxyflavone $(0.75 \mathrm{~g})(3)$, and 4',5-dihydroxy-6,7,8-trimethoxyflavone $(0.53 \mathrm{~g})(4)$, respectively.

\section{Cell lines and culture conditions}

The used cell line was RAW 264.7 (Mus musculus macrophages, SC6003). The cell line was obtained from ATCC. The cells were cultivated in DMEM (Sigma-Aldrich) containing $2 \mathrm{mM} \mathrm{L-glutamine} \mathrm{(Ap-}$ plichem), supplemented with $10 \%$ FBS (Sigma), 100 units $/ \mathrm{mL}$ of penicillin (Austria), and $100 \mu \mathrm{g} / \mathrm{mL}$ of streptomycin (Austria) in culture flasks in a $\mathrm{CO}_{2}$ incubator with a humidified atmosphere containing $5 \% \mathrm{CO}_{2}$ in air at $37^{\circ} \mathrm{C}$.

\section{Cytotoxicity assay}

For this assay, the protocol developed by Apaza et al. [33] was used. RAW 264.7 cell proliferation was analysed using a commercial LDH kit (Innoprot Company). Cells were subcultured in 96-well culture plates at a density of $1 \times 10^{4}$ cells/well in $100 \mu$ L of DMEM medium and incubated for $24 \mathrm{~h}$ at $37^{\circ} \mathrm{C}$. After $24 \mathrm{~h}$ incubation, the old medium was removed, and the cells were filled with $100 \mu \mathrm{L}$ of fresh medium and treated with the samples.

Stock solutions were prepared by dissolving the extract and the fractions in DMSO at a concentration of $20 \mathrm{mg} / \mathrm{mL}$. For the compounds, the concentration was $10 \mathrm{mM}$. Subsequently, a series of dilutions from the stock solutions were performed until a final 
DMSO concentration of $0.1 \%$ was obtained in each of the wells for each of the tested concentrations $(100,50,25,12.5,6.3,3.1,1.6$, $0.8,0.4$, and $0.2 \mu \mathrm{g} / \mathrm{mL}$ or $\mu \mathrm{M}$ ). ACT ( $\geq 95 \%$; Sigma-Aldrich, CAS Number 50-76-0) was used as a positive control at a concentration of $10 \mu \mathrm{g} / \mathrm{mL}$ (equivalent to $0.008 \mu \mathrm{M}$ for the compounds).

The treated plates were incubated in a humidified incubator at $37^{\circ} \mathrm{C}$ under a $5 \% \mathrm{CO}_{2}$ atmosphere for $6 \mathrm{~h}$. After the treatment with the samples, $100 \mu \mathrm{L}$ of culture medium supernatants were collected and incubated in the reaction mixture of the LDH kit. After 30 min, the reaction was stopped by the addition of $1 \mathrm{~N} \mathrm{HCl}$, and the absorbance at a wavelength of $490 \mathrm{~nm}$ was measured using a spectrophotometric ELISA plate reader, SpectraMax i3; Molecular Devices).

\section{TNF- $\alpha$ inhibition assay}

The protocol developed by Tena Pérez et al. [43] was used for this assay. RAW 264.7 cell $\left(1 \times 10^{4}\right.$ cells/well) were seeded on 96-well culture plates and incubated for $6 \mathrm{~h}$. The cells were then pretreated with various concentrations of the samples (extract, fractions, and compounds) for $2 \mathrm{~h}$ before stimulation with $0.1 \mu \mathrm{g} / \mathrm{mL}$ of LPS with or without samples for $6 \mathrm{~h}$. Supernatants were then collected and the protein expression levels of TNF- $\alpha$ were measured by using an ELISA kit according to the manufacturer's instructions (Diaclone Company). Absorbance was read at $450 \mathrm{~nm}$ on a spectrophotometric ELISA plate reader (Anthos 2020, Version 2.0.5; Biochrom Ltd.). The percentage of TNF- $\alpha$ inhibition was calculated from the ratio between the observed TNF- $\alpha$ amount secreted by treated cells ( $\mu \mathrm{g} /$ $\mathrm{mL}$ or $\mu \mathrm{M}$ ) and the baseline secretion of TNF- $\alpha(\mathrm{pg} / \mathrm{mL})$. C87 ( $\geq$ $98 \%$; Sigma-Aldrich, 332420-90-3) was used as a positive control at a concentration of $0.055 \mu \mathrm{g} / \mathrm{mL}$ for the extract and fractions, equivalent to $0.11 \mu \mathrm{M}$ for the compounds. Results were normalised to the DMSO solvent control (1\%).

\section{Animals}

Male Swiss mice $(25-35 \mathrm{~g})$ housed at $22 \pm 2{ }^{\circ} \mathrm{C}$ and with access to food and water ad libitum were used in these experiments. Experiments were performed during the light phase of the cycle. The animals were allowed to adapt to the laboratory for at least $1 \mathrm{~h}$ before testing and were used only once. Experiments reported in this study were performed after approval, with protocol no. 127, by the Institutional Ethics Committee of our University on June 13, 2020 and were carried out in accordance with the "Principles of Laboratory Animal Care" from NIH publication 85-23.

\section{Anti-inflammatory activity: measurement of paw oedema}

The anti-inflammatory activity of the Aq extract, fractions, and compounds of T. acutifolius was evaluated by the method of CARRinduced inflammation in the anterior paw of the mice as described by Abd-Allah et al. [44], with some modifications. Eleven groups (six mice for group) were selected for this study. Group 1 served as the negative control and received normal saline solution at a dose of $5 \mathrm{~mL} / \mathrm{kg}$ (p.o.), group 2 received CARR (300 $\mu$ g/paw, $50 \mu \mathrm{L}$ of $0.9 \%$ saline solution), group 3 received IND (98.5-100.5\%; SigmaAldrich, CAS Number 53-86-1) (5 mg/kg, p.o.) and served as the positive control, while groups 4-11 were treated with an Aq solu- tion of the extract ( $5 \mathrm{mg} / \mathrm{kg}$, p.o.), fractions ( $5 \mathrm{mg} / \mathrm{kg}$, p.o.), and compounds ( $5 \mathrm{mg} / \mathrm{kg}$, p.o.) of T. acutifolius.

Thirty minutes after intraperitoneal treatment of the animals of groups 3-11 by IND and the samples (extract, fractions, and compounds), the inflammation was induced by an injection of $50 \mu \mathrm{L}$ of the CARR solution (type IV; Sigma Chemical Company) into the right hind paw of each mouse. The thickness of the paw oedema was measured immediately after the CARR injection, and during the $6 \mathrm{~h}$ following the induction of the oedema at an interval of $1 \mathrm{~h}$ after the administration of the edematogenic agent using a plethysmometer (model 520; IITC Life Science). All the assessments were performed by the same investigator in order to reduce any potential inter-operator differences. The size of the oedema was calculated as follows:

$$
E_{\text {Oedema }} X_{t}-X_{0}
$$

$\mathrm{X}_{\mathrm{t}}$ : size of the paw oedema after edematogenic agent (CARR) injection at ' $t$ '.

$\mathrm{X}_{0}$ : size of the paw oedema before edematogenic agent (CARR) injection.

The anti-inflammatory activity was calculated as a percentage of inhibition of oedema by the extract in the treated animals under test in comparison with the CARR control group.

$$
\text { \% Inhibition }[((X-Y) / X)] * 100
$$

$\mathrm{X}$ : increase in paw oedema of the CARR group.

$Y$ : increase in paw oedema of the treated group.

The animals were sacrificed after $6 \mathrm{~h}$. The CARR-induced oedema feet were dissected and stored at $-70^{\circ} \mathrm{C}$. Blood samples were taken from anesthetised mice $6 \mathrm{~h}$ after CARR administration and kept at $-70^{\circ} \mathrm{C}$. According to the type of assay, samples were taken in citrate tubes to be centrifuged for $15 \mathrm{~min}$ at $4000 \mathrm{rpm}$, obtaining the plasma to analyse TNF- $\alpha$, in heparin tubes to be centrifuged for 15 min at 4000 rpm, obtaining the plasma to analyse CRP, and in citrate tubes to be centrifuged for $15 \mathrm{~min}$ at $4000 \mathrm{rpm}$, obtaining the plasma to analyse fibrinogen.

\section{Inflammatory parameters measurement}

Measurement of TNF- $\alpha$ serum:

Serum levels of TNF- $\alpha$ were determined using an ELISA kit according to the manufacturer's instructions (Diaclone Company). Absorbance was read at $450 \mathrm{~nm}$ on a spectrophotometric ELISA plate reader (Anthos 2020, Version 2.0.5; Biochrom Ltd.). TNF- $\alpha$ was determined from a standard curve.

\section{CRP dosage:}

The CRP was determined by the automatic analyser "COBAS INTEGRA@ 400 plus analyser” C-Reactive. The results were automatically calculated in terms of concentration. The CRP level is expressed in $\mathrm{mg} / \mathrm{L}$ of serum.

\section{Fibrinogen dosage:}

The plasma fibrinogen assay was determined according to Clauss [45] on an STA line machine. The plasmas to be tested were loaded e 
into the STA line apparatus where they were diluted with OwrenKoller buffer ( $\mathrm{pH7.35)}$ (the dilutions were carried out automatically by the apparatus). Then, the reagent STA-fibrinogen was added. The level of fibrinogen in the tested samples is expressed in $\mathrm{g} / \mathrm{L}$ of plasma.

\section{Anti-arthritic activity: measurement of paw oedema}

Experimental arthritis was induced in mice according to the method proposed by Newbould [46], with some modifications. Eleven groups (six mice for each group) were selected for this study. Group 1 served as the negative control and received normal saline solution at a dose of $5 \mathrm{~mL} / \mathrm{kg}$ (p.o.), group 2 received $0.05 \mathrm{~mL}$ (s.c.) of CFA ( 1 \% suspension in olive oil; Difco), and group 3 received IND ( $5 \mathrm{mg} / \mathrm{kg}$, p.o.) in $1 \% \mathrm{CMC}$ as a positive control. Mice in groups $4-11$ were treated with an Aq solution of the extract ( $5 \mathrm{mg} / \mathrm{kg}$, p.o.), fractions ( $5 \mathrm{mg} / \mathrm{kg}$, p.o.), and compounds ( $5 \mathrm{mg} / \mathrm{kg}$, p.o.) of T. acutifolius $24 \mathrm{~h}$ before an injection of CFA and then with a daily treatment until 14 days after the CFA injection. The oedema and inflammatory parameters were measured with the same methods described above.

\section{Statistical analysis}

$\mathrm{CC}_{50}$ and $\mathrm{IC}_{50}$ values were determined by nonlinear regression. All experiments were performed in triplicate. One-way ANOVA statistical analysis (Tukey's multiple comparisons test; ${ }^{* *} \mathrm{p}<0.01$ and $* * * p<0.001$ ) was performed to evaluate the significant differences among values. All analyses were performed using GraphPad Prism, version 9.0.0., software.

Regarding the results of the inflammatory assays in plantar oedema, the data are presented as means \pm S.E.M., except for $I D_{50}$ values (i. e., the dose of extract, fractions, and isolated compounds from $T$. acutifolius reducing the inflammatory response by $50 \%$ relative to the control value), which are reported as geometric means accompanied by their respective $95 \%$ confidence limits. Data were subjected to Student's unpaired t-test or to analysis of variance (ANOVA) complemented by Tukey's multiple comparisons test post hoc. $A^{* *} \mathrm{p}<0.01$ and ${ }^{* * *} \mathrm{p}<0.001$ was considered as indicative of significance. The $I D_{50}$ values were determined by linear regression from individual experiments using GraphPad Prism, version 9.0.0., software.

\section{Supporting information}

${ }^{1} \mathrm{H}$ - and ${ }^{13} \mathrm{C}-\mathrm{NMR},{ }^{1} \mathrm{H}-{ }^{1} \mathrm{H}$ COSY, HSQC, HMQC, HMBC, and MS spectra for the different fractions assayed in this study together with isolated compounds are provided as Supporting Information (Fig. 1S-31S).

\section{Acknowledgments}

This work was supported by the National Herbarium of Bolivia, the Fundación de la Universidad Autónoma de Madrid.

\section{Conflict of Interest}

The authors declare that they have no conflict of interest.
References

[1] Croft AP, Campos J, Jansen K, Turner JD, Marshall J, Attar M, Savary L, Wehmeyer C, Naylor AJ, Kemble S, Begum J, Dürholz K, Perlman H, Barone F, McGettrick HM, Fearon DT, Wei K, Raychaudhuri S, Korsunsky I, Brenner MB, Buckley CD. Distinct fibroblast subsets drive inflammation and damage in arthritis. Nature 2019; 570: 246-251

[2] Apaza Ticona L, Rumbero Sánchez A, Sánchez Sánchez-Corral J, Iglesias Moreno P, Ortega Domenech M. Anti-inflammatory, pro-proliferative and antimicrobial potential of the compounds isolated from Daemonorops draco (Willd.) Blume. J Ethnopharmacol 2020; 268: 113668

[3] Kuprash DV, Nedospasov SA. Molecular and Cellular Mechanisms of Inflammation. Biochemistry 2016; 81: 1237-1239

[4] Mclnnes IB, Schett G. The pathogenesis of rheumatoid arthritis. N Engl J Med 2011; 365: 2205-2219

[5] Smolen JS, Aletaha D, McInnes IB. Rheumatoid arthritis. Lancet 2016; 388: 2023-2038

[6] Liu-Bryan R. Synovium and the innate inflammatory network in osteoarthritis progression. Curr Rheumatol Rep 2013; 15: 323

[7] Isomäki P, Punnonen J. Pro- and anti-inflammatory cytokines in rheumatoid arthritis. Ann Med 1997; 29: 499-507

[8] Matsuno H, Yudoh K, Katayama R, Nakazawa F, Uzuki M, Sawai T, Yonezawa T, Saeki Y, Panayi GS, Pitzalis C, Kimura T. The role of TNF-alpha in the pathogenesis of inflammation and joint destruction in rheumatoid arthritis (RA): A study using a human RA/SCID mouse chimera. Rheumatology (Oxford) 2002; 41: 329-337

[9] Popa C, Netea MG, van Riel PL, van der Meer JW, Stalenhoef AF. The role of TNF-alpha in chronic inflammatory conditions, intermediary metabolism, and cardiovascular risk. J Lipid Res 2007; 48: 751-762

[10] Zelová H, Hošek J. TNF- $\alpha$ signalling and inflammation: interactions between old acquaintances. Inflamm Res 2013; 62: 641-651

[11] Saidenberg-Kermanac'h N, Corrado A, Lemeiter D, deVernejoul MC, Boissier MC, Cohen-Solal ME. TNF-alpha antibodies and osteoprotegerin decrease systemic bone loss associated with inflammation through distinct mechanisms in collagen-induced arthritis. Bone 2004; 35: $1200-1207$

[12] Maini RN, Elliott MJ, Brennan FM, Feldmann M. Beneficial effects of tumour necrosis factor-alpha (TNF-alpha) blockade in rheumatoid arthritis (RA). Clin Exp Immunol 1995; 101: 207-212

[13] Bournia VK, Kitas G, Protogerou AD, Sfikakis PP. Impact of non-steroidal anti-inflammatory drugs on cardiovascular risk: Is it the same in osteoarthritis and rheumatoid arthritis? Mod Rheumatol 2017; 27: 559-569

[14] Moelants EA, Mortier A, Van Damme J, Proost P. Regulation of TNF- $\alpha$ with a focus on rheumatoid arthritis. Immunol Cell Biol 2013; 91: 393-401

[15] Yamanaka H. TNF as a Target of Inflammation in Rheumatoid Arthritis. Endocr Metab Immune Disord Drug Targets 2015; 15: 129-134

[16] Radner H, Aletaha D. Anti-TNF in rheumatoid arthritis: an overview. Wien Med Wochenschr 2015; 165: 3-9

[17] Downey C. Serious infection during etanercept, infliximab and adalimumab therapy for rheumatoid arthritis: A literature review. Int J Rheum Dis 2016; 19: 536-550

[18] Stevenson M, Archer R, Tosh J, Simpson E, Everson-Hock E, Stevens J, Hernandez-Alava M, Paisley S, Dickinson K, Scott D, Young A, Wailoo A. Adalimumab, etanercept, infliximab, certolizumab pegol, golimumab, tocilizumab and abatacept for the treatment of rheumatoid arthritis not previously treated with disease-modifying antirheumatic drugs and after the failure of conventional diseasemodifying antirheumatic drugs only: Systematic review and economic evaluation. Health Technol Assess 2016; 20: 1-610 
[19] Vashisht P, O'dell J. Not all TNF inhibitors in rheumatoid arthritis are created equal: Important clinical differences. Expert Opin Biol Ther 2017; 17: 989-999

[20] Dixon W, Felson DT. Is anti-TNF therapy safer than previously thought? J Am Med Assoc 2011; 306: 2380-2381

[21] Verma PK, Bala M, Kumar N, Singh B. Therapeutic potential of natural products from terrestrial plants as TNF- $\alpha$ antagonist. Curr Top Med Chem 2012; 12: 1422-1435

[22] Nayak BN, Kaur G, Buttar HS. TNF- $\alpha$ modulation by natural bioactive molecules in mouse RAW 264.7 macrophage cells. J Complement Integr Med 2016; 13: 1-7

[23] Paul AT, Gohil VM, Bhutani KK. Modulating TNF-alpha signaling with natural products. Drug Discov Today 2006; 11: 725-732

[24] Folmer F, Jaspars M, Solano G, Cristofanon S, Henry E, Tabudravu J, Black K, Green DH, Küpper FC, Aalbersberg W, Feussner K, Dicato M, Diederich M. The inhibition of TNF-alpha-induced NF-kappaB activation by marine natural products. Biochem Pharmacol 2009; 78: 592-606

[25] Saggese D, Saggese AA. Yerbas Medicinales Argentinas: breves apuntes de las propiedades de las mismas e indicaciones para su uso. Rosario, Santa Fe-Argentina: Antognazzi \& Cia, SRL; 1950: 65-66

[26] Alice CB, Vargas VM, Silva GA, de Siqueira NC, Schapoval EE, Gleye J, Henriques JA, Henriques AT. Screening of plants used in south Brazilian folk medicine. J Ethnopharmacol 1991; 35: 165-171

[27] Muñoz V, Sauvain M, Bourdy G, Arrázola S, Callapa J, Ruiz G, Choque J, Deharo $E$. A search for natural bioactive compounds in Bolivia through a multidisciplinary approach. Part III. Evaluation of the antimalarial activity of plants used by Alteños Indians. J Ethnopharmacol 2000; 71: 123-131

[28] Macia M], Garcia E, Vidaurre P]. An ethnobotanical survey of medicinal plants commercialized in the markets of La Paz and El Alto, Bolivia. J Ethnopharmacol 2005; 97: 337-350

[29] Justo-Chipana M, Moraes RM. Medicinal plants marketed by chifleras of La Paz and El Alto cities (Bolivia). Ecol Boliv 2015; 50: 66-90

[30] Soberón JR, Sgariglia MA, Melina A, Sampietro DA, Quiroga EN, Vattuone MA.. Isolation, identification and determination of the antioxidant activity of a glycoflavonoid from Tripodanthus acutifolius (Ruiz \& Pavón) Van Tieghem. Bol Latinoam Caribe Plant Med Aromaticas 2007; 6: 276-277

[31] Soberón JR, Sgariglia MA, Sampietro DA, Quiroga EN, Vattuone MA. Study of anti-inflammatory activity of metabolites isolated from Rev. Jovens Pesqui. Mol Med Med Chem 2010; 21: 88-90

[32] Grüner JM, de Souza TK, Benitez LB, da Silva CM. Análise do perfil fitoquímico de Tripodanthus acutifolius (Ruiz \& Pavón) Tieghem, Loranthaceae. Rev Jovens Pesqui Santa Cruz do Sul 2012; 1: 9-17
[33] Apaza Ticona L, Serban AM, Cabanillas AH, Villacampa A, Rumbero Sánchez A. Flavonoids of Tripodanthus acutifolius inhibit TNF- $\alpha$ production in LPS-activated THP-1 and B16-F10 cells. J Ethnopharmacol 2019; 242: 112036

[34] Chan FKM, Moriwaki K, De Rosa MJ. Detection of necrosis by release of lactate dehydrogenase (LDH) activity. Methods Mol Biol 2013; 979: 65-70

[35] Arnott JA, Planey SL. The influence of lipophilicity in drug discovery and design. Expert Opin Drug Discov 2012; 10: 863-875

[36] Ahmad S, Israf DA, Lajis NH, Shaari K, Mohamed H, Wahab AA, Ariffin KT, Hoo WY, Aziz NA, Kadir AA, Sulaiman MR, Somchit MN. Cardamonin, inhibits pro-inflammatory mediators in activated RAW 264.7 cells and whole blood. Eur J Pharmacol 2006; 538: 188-194

[37] Takahashi A, Yamamoto N, Murakami A. Cardamonin suppresses nitric oxide production via blocking the IFN- $\gamma /$ STAT pathway in endotoxinchallenged peritoneal macrophages of ICR mice. Life Sci 2011; 89: 337-342

[38] Fehrenbacher JC, Vasko MR, Duarte DB. Models of inflammation: carrageenan- or complete Freund's adjuvant-induced edema and hypersensitivity in the rat. Curr Protoc Pharmacol 2012; 56: 5.4.1-5.4.4

[39] Mateen S, Zafar A, Moin S, Khan AQ, Zubair S. Understanding the role of cytokines in the pathogenesis of rheumatoid arthritis. Clin Chim Acta 2016; 455: 161-171

[40] Kumar LD, Karthik R, Gayathri N, Sivasudha T. Advancement in contemporary diagnostic and therapeutic approaches for rheumatoid arthritis. Biomed Pharmacother 2016; 79: 52-61

[41] McNamee K, Williams R, Seed M. Animal models of rheumatoid arthritis: How informative are they? Eur J Pharmacol 2015; 759: 278-286

[42] Ferrándiz ML, Alcaraz M]. Anti-inflammatory activity and inhibition of arachidonic acid metabolism by flavonoids. Agents Actions 1991; 32: 283-288

[43] Tena Pérez V, Apaza Ticona L, Serban AM, Acero G], Rumbero Sánchez A. Synthesis and biological screening of a library of macamides as TNF- $\alpha$ inhibitors. RSC Med Chem. 2020: 11: 1196-1209

[44] Abd-Allah A, El-Deen N, Mohamed W, Naguib FM. Mast cells and pro-inflammatory cytokines roles in assessment of grape seeds extract anti-inflammatory activity in rat model of carrageenan-induced paw edema. Iran J Basic Med Sci 2018; 21: 97-107

[45] Clauss A. Gerinnungsphysiologische schnellmethode zur bestimmung des fibrinogens. Acta Haematol 1957; 17: 237-246

[46] Newbould BB. Chemotherapy of arthritis induced in rats by mycobacterial adjuvant. Br J Pharmacol 1963; 21: 127-136e 